\title{
Analysis of the systemic problems in the regional terrestrial resources using the example of the Kalmyk republic
}

\author{
Andrei Zelenskiy \\ Volgograd Institute of management \\ - the branch of Ranepa \\ Economic faculty \\ Volgograd, Russia \\ Econaz@yandex.ru
}

\begin{abstract}
Analysis and evaluation of the land management efficiency in Kalmyk Republic according to the stages of the land relations helped to determine systemic problems and their aftereffects.
\end{abstract}

Key words - land politics, land reformation, rational land tenure, estimation of the land resources management efficiency

\section{INTRODUCTION}

At present, satisfaction of people's vital needs is increasingly being realized through the exploitation of natural resources and can lead to ecological, economic decay, loss of the necessary balance, and violation of the ecological balance in some regions.

The earth is a special, most limited and scarce resource of the modern world community. In this regard, a holistic and systematic approach to the problem of rational land use is needed. The state, as a sovereign, is obliged to continuously regulate land relations in the country, to exercise regulatory state functions for managing land resources and to create an environment for the effective use of land and its protection [1].

For the transition of the Russian Federation and its regions to the path of sustainable development, it is necessary to ensure a dynamic balance in development that allows to remove the contradictions between the needs of society in natural resources and the possibilities of their satisfaction while preserving the natural-resource potential [2].

The task of ensuring sustainable regional development based on the rationalization of the land resources use of land resources requires consideration of the land reform resources stages, their objectives, the obtained results, the identification of systemic problems, their root causes with a view to creating a conceptual model of a modern land use system that solves existing problems of practice.

\section{MATERIALS AND Methods (MODEL)}

For a holistic, comprehensive examination of the object of research and to determine its links with other phenomena, the dialectical and systemic approaches will be used to carry out the research.

In the course of study, both general scientific methods (comparisons, generalizations, decompositions, analysis, synthesis, induction, deduction, system methods), and privatescience methods (economic-mathematical, statistical, expert assessments) were used.

The official data of Rosreestr, statistical compilations, the Ministry of Land and Property Relations in the Republic of Kalmykia, the stock materials of KalmNIIgiprozem OJSC, as well as the information presented in monographs, scientific articles and publications, are the information base ensuring the representativeness of the initial data, its reliability and accuracy of the conclusions, recommendations in analytical calculations proper.

\section{RESULTS AND DISCUSSION}

At present, Russia is at the next stage of reforming agrarian law, land relations, production processes in agriculture, and therefore it is especially important to look back at all previous experience of land reforms and transformations in order to derive the best ideas of the past, to prevent mistakes of previous generations and to provide a powerful start for social and economic development of the country in the future [3].

In the Republic of Kalmykia (RK), as well as in all regions of Russia, it was essential to create a new regulatory and legal framework for regulating land relations, corresponding to new economic realities and creating conditions for rational land use. 
Based on the goals and mechanisms used, the Russian Federation, together with the subjects of the Russian Federation, underwent a number of intermediate states in the process of reform, which can be represented in the form of stages. In the Republic of Kalmykia, four stages of land reform can be distinguished:

I stage (1991-1998) - transition from state ownership to a variety of forms of ownership of land and multi-land tenure;

II stage (1999-2006) - formation of institutional bases for the development of land relations;

III stage (2007-2012) - regulation of land relations and rational land use;

IV stage (2013 - until now) - systemic land management and development of the land market [4].

To analyze the results of agrarian reforms, of which land reform was part, a comprehensive step-by-step assessment of the effectiveness of land management should be carried out, which will allow determining positive and negative trends in land use and development of land relations (Table 1).
According to Table 1, let us estimate the effectiveness of land resources management in the Republic of Kalmykia in the reform stages.

Within the first stage of the reform (1991-1998), the necessary regulatory framework for privatization and reorganization of enterprises and organizations of the agroindustrial complex was created. The procedure for determining the property shares and land shares and the direction of their use was determined.

At this stage, the foundations of the land market and its infrastructure were formed. The turnover of land in the Republic of Kalmykia included transactions with land plots held between citizens, among which 842 deals were made in 1998.

According to the Federal State Statistics Service for the Republic of Kalmykia, as a result of the reform the majority of agricultural organizations and peasant farms were found in the difficult financial situation. So the average level of return on assets of agricultural enterprises was $1.2 \%$, and the profitability of products in general was negative $-12.1 \%$.

TABLE I. ESTIMATION OF THE LAND MANAGEMENT EFFICIENCY IN THE REPUBLIC OF KALMYKIA

\begin{tabular}{|c|c|c|c|c|c|}
\hline Indices of the land resources efficiency estimation & $\begin{array}{c}\text { Pre reform } \\
\text { period } \\
(1990)\end{array}$ & $\begin{array}{l}1 \text { stage of the } \\
\text { land reform } \\
(1991-1998)\end{array}$ & $\begin{array}{l}\text { IInd stage of the } \\
\text { reform }(1999 \text { - } \\
2006)\end{array}$ & $\begin{array}{l}\text { IIIrd stage of } \\
\text { the reform } \\
(2007-2012)\end{array}$ & $\begin{array}{l}\text { IVth }(2013- \\
\text { until now) }\end{array}$ \\
\hline \multicolumn{6}{|c|}{ Technological compound } \\
\hline Proportion of plowland under the heirs \% & 78,71 & 47,44 & 29,82 & 26,64 & 27,53 \\
\hline Proportion of the "black" fallow, $\%$ & - & 16,8 & 10,16 & 8,66 & 8,97 \\
\hline Proportion of the non used arale land, $\%$ & - & 35,76 & 60,02 & 64,70 & 63,50 \\
\hline Crop capacity of the grain crops $\mathrm{q} / \mathrm{ha}^{*}$ & 21,4 & 10,9 & 16,2 & 17,4 & 18,8 \\
\hline Perennial plants hay capacity, $\mathrm{q} / \mathrm{ha}^{*}$ & 52,0 & 18,4 & 25,0 & 25,5 & 21,4 \\
\hline Index of the excss overstress to the norm & 2,6 & 1,9 & 1,4 & \multicolumn{2}{|c|}{$\begin{array}{l}\text { Geobotanic examination was not } \\
\text { carried out }\end{array}$} \\
\hline \multicolumn{6}{|c|}{ Organization legal compound } \\
\hline Allocated rights by the land proprietor, th/ha & - & 180 & 344,7 & 1230,2 & 1102,8 \\
\hline Number of deals with the land lots, un. & - & 842 & 6292 & 9532 & 10639 \\
\hline $\begin{array}{l}\text { Number of the tests in the framework of the land control, } \\
\text { un. }\end{array}$ & - & 1131 & 505 & 1428 & 919 \\
\hline Number of the detected violations, un. & - & 598 & 152 & 269 & 159 \\
\hline Amount of the exacted fines, thousand. rub. & - & 38,1 & 498,5 & 284,9 & 206,0 \\
\hline Proportion of the eliminaated precept, $\%$ & - & 97 & 100 & 63,5 & 50,3 \\
\hline \multicolumn{6}{|c|}{ Social and economic compound } \\
\hline Recept of the land tax to the budget, млн. руб. & - & 9,5 & 52,2 & 183,4 & 231,8 \\
\hline Profitability of the agriculturul enterprises products, $\% *$ & - & $-12,1$ & 14,4 & 15,7 & 6,7 \\
\hline Profitability of the agricultural enterprises asets, $\% *$ & - & 1,2 & 3,9 & 7,6 & 3,8 \\
\hline \multicolumn{6}{|c|}{ Ecological compound } \\
\hline Acreage subject to the wind erosio, thousand/ha & 1744,9 & 1789,9 & 4469,8 & \multirow{6}{*}{\multicolumn{2}{|c|}{$\begin{array}{c}\text { Soil examination was not carried } \\
\text { out }\end{array}$}} \\
\hline -acreage of the eroded land, thousand/ha & 438,2 & 430,7 & 516,1 & & \\
\hline -acreage of the saline soil, thousand/ha & 2469,2 & 2653,2 & 2423,5 & & \\
\hline -acreage of the alkaline soil, thousand/ha & 4366,9 & 4342,2 & 4304,9 & & \\
\hline -acreage under degumification, thousand/ha & 936,8 & 936,8 & 936,8 & & \\
\hline - area of downed pastures, thousand/ha & 2690,8 & 3857,2 & 3272,4 & & \\
\hline \multicolumn{6}{|c|}{ Information compound } \\
\hline Soil examinations, thousand/ha & 6492,6 & 1660,0 & 343,9 & \multicolumn{2}{|c|}{$\begin{array}{c}\text { Soil examination was not carried } \\
\text { out }\end{array}$} \\
\hline Geobotanic studies, thousand/ha & 5321,9 & 3883,4 & 374,4 & \multicolumn{2}{|c|}{$\begin{array}{c}\text { Geobotanic examination was not } \\
\text { carried out }\end{array}$} \\
\hline Aerophoto taking, thousand/ha' & 7473,1 & 3740,4 & 424,9 & 0,0 & 45,4 \\
\hline
\end{tabular}

* - in average for a stage of reforming of land resources in the Republic of Kalmykia 
The first stage of the reform in the agrarian sector did not solve the assigned tasks. The new agricultural entities arising from the reorganization of agricultural enterprises could neither improve the efficiency of agricultural production and increase the productivity of agricultural land (the yield of cereals on average dropped almost 2 times from 21.4 to 10.9 centner/ ha, and perennial grasses - 2.8 times), nor improve their use. Owners of land shares did not fully realize their rights at their disposal. The transition of land to efficient economic entities was extremely slow; the mortgage lending system was not created.

The transition to the program target management method at the second stage of the reform (1999-2006) necessitated change in the land policy, cadastre and monitoring system. According to the results of the stage (as of 01.01.2007), the land shares of citizens (including shares in the right of common joint ownership) in the land fund of the republic in total amount of only $5.5 \%$ (410.9 thousand ha) or $95.9 \%$ of the land in private ownership in the republic. Land owners realized 344.7 thousand hectares of land rights shares.

Out of 7,044,500 hectares of land in state and municipal ownership within the borders of the Republic of Kalmykia, at present, only $11 \%$ are registered with the right of public entities ownership.

More than 6 million hectares of land on the territory of the Republic were allocated to unrestricted lands that are in state ownership, the right of which was granted to district municipal entities.

During the second stage, there was a steady trend of deterioration of the state productive agricultural lands, so the area of land subjected to wind erosion increased by 2.5 times, and eroded land - 1.2 times.

The structure of land relations formed by the time of the third stage (2007-2012), determined the need to increase the land and resource potential, the development of turnover and the formation of the agricultural land market, the optimization of payments for land.

The agro-technical condition of arable lands depends on the sown areas structure, as well as on the structure of agricultural lands, which are an important part of ecologically balanced agriculture. Over the past twenty years, the share of unused arable land in the Republic of Kalmykia has increased (by the end of the third stage, their share was $64.70 \%$ ). In addition, the structure of sown areas was formed without taking into account the environmental factor. A high percentage of cereals, and, above all, spring wheat and barley, the lack of crop rotation has led to a decline in soil fertility.

The process of registering the right of ownership of the Republic of Kalmykia and municipal entities to land plots was delayed. The effectiveness of state and municipal property management on land remained low, which led to a 1.8-fold increase in violations of land legislation (from 152 to 269 units).

The fourth stage of the reform (2013 - up to the present) was designed to improve the management tools of land resources for ensuring rational land use.
In the republic there were significant areas of "undivided" land, primarily, agricultural land. The lack of registered rights to land from municipal entities did not contribute to investment attractiveness, economic stability and increased financial results of agricultural producers (on average during the fourth stage, the profitability level of assets of agricultural enterprises was 2.3 , and the profitability of production was 2 times lower than in the third period). All this led to a shortage of financial revenues to the local budget, which requires further reform of land relations.

The lack of a modern land information system in the Republic of Kalmykia, which contains information on the number and quality of agricultural land, the results of space and aerial surveys, mapping, soil and geobotanical surveys, which have not been conducted in the country for the last twenty years, have led to a decrease in land administration efficiency.

The state of the region's land management system is currently a state of "bifurcation", a kind of degeneration, a crisis, the transition of the system from one principled state to another.

In the period of radical transformation of the system for its development and stabilization, it is necessary to restore prefurcation conditions on the one hand (to ensure the stability of the system), and on the other to create new conditions that are appropriate to the situation (to ensure the development of the system) [5].

In this regard, it is necessary to comply with the requirements of the nature use laws, ignoring problems in the practice of land management in order to ensure rational and economically efficient land management, protection and protection of the natural environment.

The main provisions of the laws of nature management, grouped by Reimers NF [6], "are directly related to the use of land as an essential component of nature ... they are more or less related to the protection and use of land and they must be taken into account in the process of land management" [7].

Analysis of the land use resources and assessment of the components of the land administration system, the determination of their effectiveness have made it possible to identify the problems characteristic of the Republic of Kalmykia. Study of the works of S.N. Volkova, N.V. Komova, V.N. Khlystuna [8], A.A. Varlamov, P.F. Loiko [9], V.V. Alakoza, D.A. Ovsyannikova [10] made it possible to supplement the list of violations of the application of the nature laws management in the practice of managing land resources in the regions and determine the negative consequences caused (Table 2).

Each of the above laws reveals the inherent aspect of nature. But all of them are, in one way or another, connected with the protection and use of land, they must be taken into account in the process of land management. In the course of the study, the causes (prerequisites) of inefficient land management, the problems they caused and the negative consequences were systematized. 
TABLE II. THE MAIN PROBLEMS ARISING FROM THE VIOLATION OF THE LAWS OF NATURE

\begin{tabular}{|c|c|c|}
\hline Laws of nature use & $\begin{array}{l}\text { Ignoring the main provisions of the law in the management } \\
\text { of land resources }\end{array}$ & Challenges in the use of land resources \\
\hline $\begin{array}{l}\text { 1. The law of limited } \\
\text { (exhaustible) natural resources }\end{array}$ & $\begin{array}{l}\text { 1. The erroneous idea of the infinity and inexhaustibility of soil } \\
\text { resources. } \\
\text { 2. Land use without taking into account natural, economic, social } \\
\text { and political conditions. } \\
\text { 3. Absence of land management projects with a complex of } \\
\text { nature protection measures. }\end{array}$ & $\begin{array}{l}\text { 1. Steady tendency to decrease soil fertility. } \\
\text { 2. Development of degradation processes. } \\
\text { 3. Reducing the area of agricultural land. }\end{array}$ \\
\hline $\begin{array}{l}\text { 2. The law of correspondence } \\
\text { between the development of } \\
\text { productive forces and the } \\
\text { natural potential of social } \\
\text { progress (the rule of basic } \\
\text { exchange) }\end{array}$ & $\begin{array}{l}\text { 1. A flexible and diverse system of land use has not been created. } \\
\text { 2. Significant reduction in the number of land management } \\
\text { projects and farming systems. } \\
\text { 3. Destruction of design and estimate practice in land } \\
\text { management. }\end{array}$ & $\begin{array}{l}\text { 1. The land-use system does not ensure the rational } \\
\text { distribution and effective use of land as a spatial basis for } \\
\text { locating productive forces and a vital natural resource. } \\
\text { 2. Often there is no scientific basis for rational (cost-effective } \\
\text { and environmentally safe) land use. }\end{array}$ \\
\hline $\begin{array}{l}\text { 3. The law of decreasing } \\
\text { (natural) fertility }\end{array}$ & $\begin{array}{l}\text { 1. Irrational use of arable and pasture lands. } \\
\text { 2. Failure to comply with the optimal structure of arable land and } \\
\text { cultivated areas. } \\
\text { 3. Reducing the volume of mineral and organic fertilizers. } \\
\text { 4. Violation of the technology of cultivation of crops. } \\
\end{array}$ & $\begin{array}{l}\text { 1. Decrease in productivity of agricultural crops and } \\
\text { productivity of pasture lands. } \\
\text { 2. Degumification of soils. } \\
\text { 3. Low soil ability to self-repair, unsatisfactory state of soil } \\
\text { biota, agroprostitution. }\end{array}$ \\
\hline $\begin{array}{l}\text { 4. The law reducing the } \\
\text { energy efficiency of nature } \\
\text { management (law of } \\
\text { diminishing returns) }\end{array}$ & $\begin{array}{l}\text { 1. The work on increasing the fertility of soils and the } \\
\text { arrangement of territories has been completed. } \\
\text { 2. Due to insufficient financing, the material base of the agro- } \\
\text { industrial complex has been weakened and largely obsolete. } \\
\text { 3. Non-observance of crop rotations and pasture rotation. }\end{array}$ & $\begin{array}{l}\text { 1. The growth rate of land degradation. } \\
\text { 2. Low level of the system of farming. } \\
\text { 3. Decrease in profitability of agricultural production. } \\
\text { 4. Decrease in productivity of agricultural lands. }\end{array}$ \\
\hline $\begin{array}{l}\text { 5. The law of the fall of the } \\
\text { natural resource potential }\end{array}$ & $\begin{array}{l}\text { 1. Non-economic use of agricultural land. } \\
\text { 2. When using land economically, weak soil stability to } \\
\text { anthropogenic impact is not taken into account. } \\
\text { 3. The presence of an ecological imbalance in the ratio of land } \\
\text { (arable land, forest, natural fodder land) in regional land use } \\
\text { systems. } \\
\text { 4. Violation of the norms of loading on agricultural land (lack of } \\
\text { clean fumes and overgrazing in pastures). }\end{array}$ & $\begin{array}{l}\text { 1. Degradation of agricultural land. } \\
\text { 2. Deterioration of the quality of soil and plant resources. } \\
\text { 3. Transfer of land to a less valuable category. } \\
\text { 4. Decrease in the tax base for land tax. }\end{array}$ \\
\hline $\begin{array}{l}\text { 6. The law of the aggregate } \\
\text { (joint) action of natural factors }\end{array}$ & $\begin{array}{l}\text { 1. The organization of farms does not take into account the } \\
\text { natural and climatic conditions of the territory. } \\
\text { 2. Adaptive-landscape approach to the location of crops is not } \\
\text { applied. }\end{array}$ & $\begin{array}{l}\text { 1. Development of processes of water and wind erosion, } \\
\text { desertification of the territory, salinization, waterlogging, } \\
\text { flaring, impoverishment of soils. } \\
\text { 2. The methodology and theory of organization of the territory } \\
\text { on an ecologically-landscape basis has not been fully } \\
\text { developed. }\end{array}$ \\
\hline
\end{tabular}

Despite the low cadastral value and low natural potential, the land resources of Kalmykia are a strategically important resource for the economy of the republic, which, in many respects, provides for its needs, while agricultural producers receive the necessary income. The constant monitoring of the state of land resources is important here, which confirms that the threshold of ecologically permissible impact on land on the territory of the republic is limited and is associated with the violation of the principles of agrarian nature management. This was reflected in the degradation of land resources used in the agrarian sector, the depletion of water sources, pollution of the atmosphere.

In addition to the laws of nature management, it is necessary to take into account the laws of management.

The laws of management express the most significant links and relationships of the various elements of the management systems between themselves and with the external environment. The main provisions of the laws of management are formulated by O.D. Lebedev, A.R. Kankovskaya [12], V.I. Mukhin [13], A.A. Varlamov [14] is also true of the use of land. On the basis of the conducted analysis of the effectiveness of land resources management and the study of the works S.N. Volkova, N.V. Komova, V.N. Khlystuna [8],
A.A. Varlamov, P.F. Loiko [9], V.V. Alakoza, D.A. Ovsyannikova [10], T.I. Bakinova [11] made it possible to identify violations of the law of the administration of the land administration system (Table 3 ).

The management is an integral element in the management of the agrarian economy with its own characteristics, which are determined by the specific nature of the land as an object of socio-ecological and economic relations and, at the same time, a natural resource. This aspect should be taken into account in the formation of a common management system for agricultural land.

Difficulties of economic and ecological character in modern land relations in the region arose as a result of unpreparedness of the adopted normative and legal acts, deeprooted structural distortions in the agrarian economy, backward technology and technology and inefficient management.

These circumstances hamper the formation and development of land relations, serve as the reasons for the emergence in this sphere of complex and acute problems that are urgently demanding their solution within the framework of the implementation of a thoughtful state land policy. 
TABLE III. THE MAIN PROBLEMS ARISING IN VIOLATION OF THE MANAGEMENT LAW

\begin{tabular}{|c|c|c|}
\hline $\begin{array}{l}\text { Laws of management and } \\
\text { their content }\end{array}$ & Violation of the application of laws in practice & $\begin{array}{l}\text { The challenges in the functioning of the land } \\
\text { administration system }\end{array}$ \\
\hline $\begin{array}{l}\text { 1. The law of unity and integrity } \\
\text { of the management system }\end{array}$ & $\begin{array}{l}\text { 1. Absence of a government body with clearly defined tasks and } \\
\text { functions, with the authority to make decisions in the field of land } \\
\text { policy at the federal level. } \\
\text { 2. The incompleteness of land reforms. }\end{array}$ & $\begin{array}{l}\text { 1. Duplication of functions, inconsistency of } \\
\text { administrative influences. } \\
\text { 2. The presence of citizens who are legally undetermined } \\
\text { and not allocated in kind of land shares on the area of } \\
\text { more than } 100 \text { million hectares of agricultural land. }\end{array}$ \\
\hline $\begin{array}{l}\text { 2. The law of conservation of } \\
\text { proportionality and rational } \\
\text { combination of all elements of } \\
\text { any management system }\end{array}$ & $\begin{array}{l}\text { 1. Destruction of the system of training specialists in the field of } \\
\text { regulation of land relations and land management. } \\
\text { 2. The process of delimitation of the lands of the Republic of } \\
\text { Kalmykia and municipalities has not been completed. }\end{array}$ & $\begin{array}{l}\text { 1. Deprofessionalization of specialists, leading to a low } \\
\text { level of land management and cadastral work. } \\
\text { 2. The process of registering the ownership rights of the } \\
\text { RK and municipal entities for land plots is very slow and } \\
\text { not completed to the present. }\end{array}$ \\
\hline $\begin{array}{l}\text { 3. The law of the effectiveness of } \\
\text { the management system, } \\
\text { depending on the volume of } \\
\text { information used }\end{array}$ & $\begin{array}{l}\text { 1. Lack of modern technologies for obtaining, processing and } \\
\text { disseminating information on the state of the land fund. } \\
\text { 2. Significant reduction in the volume of work on large-scale soil } \\
\text { and geobotanical surveys. }\end{array}$ & $\begin{array}{l}\text { 1. The growing misinformation of the government and } \\
\text { the population of the country on the composition, } \\
\text { structure and dynamics of changes in the state of the land } \\
\text { fund. } \\
2 . \text { Non-objective qualitative characteristics of lands used } \\
\text { for land cadastre, land use planning and other purposes. }\end{array}$ \\
\hline $\begin{array}{l}\text { 4. The law of unity and co- } \\
\text { ordination of efficiency criteria } \\
\text { used in the management process }\end{array}$ & $\begin{array}{l}\text { 1. Insufficient development of the foundations of land policy, } \\
\text { regional and local strategies for the use and protection of } \\
\text { agricultural land. } \\
\text { 2. Lack of a unified methodology for assessing the effectiveness of } \\
\text { land management. }\end{array}$ & $\begin{array}{l}\text { 1. Imperfection of the organization of optimal } \\
\text { agricultural land use. } \\
2 . \text { The use of inefficient mechanisms by the state bodies } \\
\text { in the management of land resources. }\end{array}$ \\
\hline $\begin{array}{l}\text { 5. The law of compatibility of the } \\
\text { technical means and systems of } \\
\text { control of the co-ordinated and } \\
\text { interacting systems }\end{array}$ & $\begin{array}{l}\text { 1. Absence of a clear distribution of powers between public } \\
\text { authorities and local governments in land administration. } \\
\text { 2. Not complete comparability of data generated by land-cadastral } \\
\text { services used in land management. }\end{array}$ & $\begin{array}{l}\text { 1. Increased costs for land management. } \\
\text { 2. Limit the possibilities for conducting analysis and } \\
\text { making effective management decisions. }\end{array}$ \\
\hline
\end{tabular}

\section{CONCLUSION}

The conducted analysis of the effectiveness of land management showed that the land reform carried out in the Republic of Kalmykia for 25 years did not ensure or promote the increase of productivity of land and living standards of the region population; neither did it pay enough attention to the environmental and economic consequences of land reforms. In this regard, land reform should be aimed at increasing the efficiency of land use by developing and implementing a set of interrelated legal, organizational, financial, scientific and technical, land management and other measures to ensure the creation of an effective mechanism for regulating land relations and public land management.

Defining the specifics of land relations in the transition period, it is necessary to take into account that it is the features of the land, as a unique productive resource, that objectively require, under any socioeconomic order, adequate and versatile government intervention in relations regarding the distribution, redistribution, use and restoration of land resources.

To increase the effectiveness of land resources management, it is necessary to continue the formation of the landed property of the republic by using the pre-emptive right to purchase land plots by the republic, to uncover and register unclaimed land shares. Develop and implement a clear program of measures to complete the land reforms in rural areas, the content of which should specify the list and terms for approving the necessary subordinate legislation, measures to create an adequate system of bodies for regulating land relations and organizing rational use of land, measures to stimulate the development of land infrastructure market, cadastral, technical, information and other support for the creation of an integrated system of ordering rights and regulation land relations.

\section{References}

[1] Loiko P.F. Land reforms in Russia in 1991-2006: errors and miscalculations: ways out of the crisis state of modern land use of the country // Land management, cadastre and monitoring of land, 2006. No. 7, pp. 4-13

[2] Vorontsov A.P. Environmental economics. M .: IKF "EKMOS", 2002, pp.3-6

[3] Vershinin VV, Kovaleva T.N. Improvement of land management support for the socio-economic development of the agroindustrial complex (historical experience of land reforms in Russia) // Land management, cadastre and land monitoring, 2012. № . 1, p. 23

[4] Zelensky A.G. Stages and evaluation of the results of land reform in the Republic of Kalmykia // Land management, cadastre and land monitoring. 2017. № 7, pp.34-43.

[5] Mogilevsky V.D. Methodology of systems. - Moscow: Economics. 1999, pp.22-30

[6] Reimers N.F. Nature management. Dictionary-reference book. M : Mysl, 1990, pp.142-167

[7] Shelyakov I.M., Stafiychuk I.D., Gabaidullina G.R. On the issue of land management // Land management, cadastre and land monitoring, 2013 № 4, pp. 30-37

[8] Khlystun V.N., Volkov S.N., Komov N.V. Management of land resources in Russia // Economics of agricultural and processing enterprises, 2014. № 2, pp.41-43

[9] Varlamov A.A., Loiko P.F. Problems of land resources management in the Russian Federation // Land management, cadastre and land monitoring, 2005. № 9, pp.4-12

[10] Alakoz V.V., Ovsyannikov D.A. The system of organization of optimal agricultural land use // Land management, cadastre and land monitoring, 2014. № 12, pp.6-17 
[11] Bakinova T.I. Ecological and economic problems of the agricultural farming in the arid zone. Rostov-on-Don, SKNT VS, 2000, pp. 85-97.

[12] Lebedev OT, Kankovskaya A.R. Fundamentals of management. Textbook - S.-P .:"MiM" Publishing House, 1997.
[13] Mukhin V.I. Fundamentals of control theory. Textbook / B.И. Mukhin M .: Examen, 2002. - pp. 74-82.

[14] Varlamov A.A. Land cadastre: Vol. 2 of 6 Vol. Land management. Moscow: Colos, 2005. - pp. 17-21. 